\title{
GATA4 and GATA5 are potential tumor suppressors and biomarkers in colorectal cancer
}

Citation for published version (APA):

Hellebrekers, D. M., Lentjes, M. H., van den Bosch, S. M., Melotte, V., Wouters, K. A., Daenen, K. L., Smits, K. M., Akiyama, Y., Yuasa, Y., Sanduleanu, S., Khalid - de Bakker, C. A., Jonkers, D., Weijenberg, M. P., Louwagie, J., van Criekinge, W., Carvalho, B., Meijer, G. A., Baylin, S. B., Herman, J. G., ... van Engeland, M. (2009). GATA4 and GATA5 are potential tumor suppressors and biomarkers in colorectal cancer. Clinical Cancer Research, 15(12), 3990-7. https://doi.org/10.1158/1078-0432.CCR-09-0055

Document status and date:

Published: 01/01/2009

DOI:

10.1158/1078-0432.CCR-09-0055

Document Version:

Publisher's PDF, also known as Version of record

\section{Document license:}

Taverne

\section{Please check the document version of this publication:}

- A submitted manuscript is the version of the article upon submission and before peer-review. There can be important differences between the submitted version and the official published version of record.

People interested in the research are advised to contact the author for the final version of the publication, or visit the DOI to the publisher's website.

- The final author version and the galley proof are versions of the publication after peer review.

- The final published version features the final layout of the paper including the volume, issue and page numbers.

Link to publication

\footnotetext{
General rights Owners
rights.

- You may freely distribute the URL identifying the publication in the public portal. please follow below link for the End User Agreement:

www.umlib.nl/taverne-license

Take down policy

If you believe that this document breaches copyright please contact us at:

repository@maastrichtuniversity.nl

providing details and we will investigate your claim.
}

Copyright and moral rights for the publications made accessible in the public portal are retained by the authors and/or other copyright owners and it is a condition of accessing publications that users recognise and abide by the legal requirements associated with these

- Users may download and print one copy of any publication from the public portal for the purpose of private study or research.

- You may not further distribute the material or use it for any profit-making activity or commercial gain

If the publication is distributed under the terms of Article $25 \mathrm{fa}$ of the Dutch Copyright Act, indicated by the "Taverne" license above, 


\title{
GATA4 and GATA5 are Potential Tumor Suppressors and Biomarkers in Colorectal Cancer
}

\author{
Debby M.E.I. Hellebrekers, ${ }^{1}$ Marjolein H.F.M. Lentjes, ${ }^{1}$ Sandra M. van den Bosch, ${ }^{1}$ Veerle Melotte, ${ }^{1}$ \\ Kim A.D.Wouters, ${ }_{1}^{1}$ Kathleen L.J. Daenen, ${ }^{1}$ Kim M. Smits, ${ }^{2}$ Yoshimitsu Akiyama, ${ }^{4}$ Yasuhito Yuasa, ${ }^{4}$ \\ Silvia Sanduleanu, ${ }^{3}$ Carolina A.J. Khalid-de Bakker, ${ }^{3}$ Daisy Jonkers, ${ }^{3}$ Matty P. Weijenberg, ${ }^{2}$ \\ Joost Louwagie, ${ }^{5}$ Wim van Criekinge, ${ }^{5}$ Beatriz Carvalho, ${ }^{6}$ Gerrit A. Meijer, ${ }^{6}$ Stephen B. Baylin, ${ }^{7}$ \\ James G. Herman, ${ }^{7}$ Adriaan P. de Bruïne, ${ }^{1}$ and Manon van Engeland ${ }^{1}$
}

\begin{abstract}
Purpose: The transcription factors GATA4 and GATA5 are involved in gastrointestinal development and are inactivated by promoter hypermethylation in colorectal cancer. Here, we evaluated GATA4/5 promoter methylation as potential biomarkers for noninvasive colorectal cancer detection, and investigated the role of GATA4/5 in colorectal cancer.

Experimental Design: Promoter methylation of GATA4/5 was analyzed in colorectal tissue and fecal DNA from colorectal cancer patients and healthy controls using methylation-specific PCR. The potential function of GATA $4 / 5$ as tumor suppressors was studied by inducing GATA $4 / 5$ overexpression in human colorectal cancer cell lines.

Results: GATA4/5 methylation was observed in 70\% (63/90) and 79\% (61/77) of colorectal carcinomas, respectively, and was independent of clinicopathologic features. Methylation frequencies in normal colon tissues from noncancerous controls were $6 \%$ (5 of 88, GATA4; $P$ < $0.001)$ and $13 \%(13$ of 100, GATA5; $P<0.001)$. GATA $4 / 5$ overexpression suppressed colony formation $(P<0.005)$, proliferation $(P<0.001)$, migration $(P<0.05)$, invasion $(P<0.05)$, and anchorage-independent growth $(P<0.0001)$ of colorectal cancer cells. Examination of GATA4 methylation in fecal DNA from two independent series of colorectal cancer patients and controls yielded a sensitivity of $71 \%$ [ $95 \%$ confidence interval $(95 \% \mathrm{Cl}), 55-88 \%$ ] and specificity of $84 \%$ $(95 \% \mathrm{Cl}, 74-95 \%)$ for colorectal cancer detection in the training set, and a sensitivity of $51 \%$ $(95 \% \mathrm{Cl}, 37-65 \%)$ and specificity of $93 \%(95 \% \mathrm{Cl}, 84-100 \%)$ in the validation set.

Conclusions: Methylation of GATA4/5 is a common and specific event in colorectal carcinomas, and GATA4/5 exhibit tumor suppressive effects in colorectal cancer cells in vitro. GATA4 methylation in fecal DNA may be of interest for colorectal cancer detection.
\end{abstract}

Authors' Affiliations: Departments of ${ }^{1}$ Pathology and ${ }^{2}$ Epidemiology, GROW School for Oncology and Developmental Biology, and ${ }^{3}$ Divison of Gastroenterology and Hepatology, Department of Internal Medicine, Maastricht University Medical Center, Maastricht, the Netherlands, ${ }^{4}$ Department of Molecular Oncology, Graduate School of Medicine and Dentistry, Tokyo Medical and Dental University, Tokyo, Japan, ${ }^{5}$ OncoMethylome Sciences SA, Liege, Belgium, ${ }^{6}$ Department of Pathology, VU University Medical Center, Amsterdam, the Netherlands, and ${ }^{7}$ The Sidney Kimmel Comprehensive Cancer Center at Johns Hopkins, Baltimore, Maryland

Received 1/10/09; revised 3/11/09; accepted 3/20/09; published OnlineFirst 6/9/09. Grant support: SenterNovem (grant ISO52034); ZonMW (grant 6120.0022).

The costs of publication of this article were defrayed in part by the payment of page charges. This article must therefore be hereby marked advertisement in accordance with 18 U.S.C. Section 1734 solely to indicate this fact.

Note: Supplementary data for this article are available at Clinical Cancer Research Online (http://clincancerres.aacrjournals.org/).

D.M.E.I. Hellebrekers and M.H.F.M. Lentjes contributed equally to this work.

Requests for reprints: M. van Engeland, Department of Pathology, GROW School for Oncology and Developmental Biology, Maastricht University Medical Center, P.O.Box 616, 6200 MD Maastricht, the Netherlands. Phone: 31-433874622; Fax: 31-43-3876613; E-mail: manon.van.engeland@mumc.nl.

(C) 2009 American Association for Cancer Research.

doi:10.1158/1078-0432.CCR-09-0055
Early detection of colorectal cancer and high-risk precursor lesions will improve cure rates (1). The gold standard for colorectal cancer detection is colonoscopy, but due to its invasive nature, many patients refrain from undergoing colonoscopy. Therefore, noninvasive screening modalities to select patients at risk of colorectal cancer for colonoscopy, are needed. Currently, testing for the presence of fecal occult blood is used $(2,3)$. Despite its low sensitivity, fecal occult blood testing has been shown to reduce the incidence and risk of colorectal cancer death when used programmatically $(1,2$, $4,5)$. A promising noninvasive colorectal cancer screening modality is the detection of colorectal cancer-specific genetic alterations in stool-derived DNA (6-9), but it needs improvement in terms of sensitivity and cost effectiveness.

Promoter $\mathrm{CpG}$ island hypermethylation analysis of serum and feces has the potential to be used as a noninvasive test for the early diagnosis of (colorectal) cancers $(10-15)$. However, because promoter methylation is also associated with aging (16) and chronic inflammation (17-19), proper selection of 


\section{Translational Relevance}

Detection of aberrantly methylated tumor suppressor genes in stool DNA of colorectal cancer patients provides an attractive strategy for noninvasive and early detection of colorectal cancer. The current article shows that GATA4/5 promoter methylation is an early, frequent, and specific event in colorectal cancer, independent of clinicopathologic features. We also show that GATA4 methylation is a sensitive and specific biomarker for colorectal cancer detection in stool DNA. In addition, we partly unraveled the function of GATA4 and GATA5 in colorectal cancer, by showing that these proteins suppress colony formation, proliferation, migration, invasion, and anchorage-independent growth of colorectal cancer cells, indicating a tumor suppressor role of GATA4 and GATA5 in colorectal cancer. To our knowledge, this is the first study that (a) reports on the tumor suppressive effects of GATA4 and GATA5 in colorectal cancer, and $(b)$ shows that GATA4 methylation is a promising biomarker for early colorectal cancer screening in stool DNA.

methylation markers is crucial for sensitive and specific detection of colorectal cancer.

Transcription factors GATA4 and GATA5 play an essential role in the development and differentiation of the gastrointestinal tract and are suggested to be involved in colorectal cancer development $(20-23)$. However, the (tumor suppressor) function of these genes is poorly understood.

Here we examined promoter hypermethylation of GATA4/5 in large, well-characterized series of colorectal cancers and noncancerous colorectal mucosa, and compared GATA4/5 methylation frequencies with those of other genes functionally involved and frequently methylated in colorectal cancer. In addition, we investigated the function of GATA4/5 in human colorectal cancer cells by transfecting these cells with a GATA4/ 5 expression vector and measuring colony formation, proliferation, migration, invasion, and anchorage-independent growth. Finally, we evaluated the use of GATA4 methylation in fecal DNA as a potential biomarker for early colorectal cancer detection.

\section{Materials and Methods}

Study population. Formalin-fixed, paraffin-embedded colorectal mucosa tissue of colorectal cancer patients $(n=102)$ and patients without cancer $(n=230)$ over $50 \mathrm{y}$ of age were retrospectively collected from the archive of the Department of Pathology of the Maastricht University Medical Center (Supplementary Fig. S1, Supplementary Table S1, and Supplementary Methods). An additional, independent set of 716 paraffin-embedded colorectal cancers was derived from patients participating in the prospective Netherlands Cohort Study on Diet and Cancer (NLCS; refs. 24, 25). Tissue samples were handled and analyzed in a blinded fashion during collection, storage, DNA isolation, and PCR analysis. This study was approved by the Medical Ethical Committee of the Maastricht University Medical Center.

Methylation-specific PCR, BRAF mutation and microsatellite instability analysis. A 5- $\mu \mathrm{m}$ section of each tissue block was stained with H\&E and revised by a pathologist (AdB). Five $20-\mu \mathrm{m}$ sections were deparaffinated prior to DNA-isolation using the Puregene DNA Isolation Kit (Gentra Systems; Qiagen). Promoter CpG island methylation of GATA4, GATA5, APC, p14 $4^{A R F}, \mathrm{O}^{6}-M G M T, H L T F, p 16^{I N K 4 A}$, and
RASSF 1A was determined by sodium bisulfite treatment of genomic DNA followed by methylation-specific PCR (MSP) as described elsewhere $(25,26)$. For primer sequences and MSP conditions, see Supplementary Table S2. For analysis of $B R A F$ mutation and microsatellite instability, see Supplementary Methods.

Cell culture and transfections. Human HCT116 and RKO colorectal cancer cell lines were cultured in DMEM (Invitrogen) containing 10\% fetal bovine serum (HyClone)

Full-length GATA4/ 5 cDNAs subcloned into the pcDNA3 vector were named pcDNA3-GATA4 and pcDNA3-GATA5. RKO cells were transfected using Lipofectamine 2000 Reagent (Invitrogen) according to the manufacturer's protocol. After selection for 2 to 3 wk with $1 \mathrm{mg} / \mathrm{mL}$ geneticin (G418; Invitrogen), individual clones were isolated. RKO clones constitutively expressing GATA4/5 protein, named pc-GATA4-1 and pc-GATA5-1, were maintained in medium containing G418 $(1 \mathrm{mg} / \mathrm{mL})$ and used for further experiments. Three RKO clones constitutively expressing empty vector (pc-con-1, pc-con-2, and pc-con-3) were used, and results of these three clonal lines were averaged and named pccon(1-3). HCT116 cells were transfected with the Nucleofector Kit V (Amaxa Biosystems) using the manufacturer's guidelines. Although up to 30 single colonies were picked after 2 to 3 wk selection with $400 \mu \mathrm{g} / \mathrm{mL}$ G418, HCT116 clonal lines constitutively expressing GATA4/5 protein could not be maintained. Therefore, HCT116 cells were transfected with control construct (empty vector; pcDNA3), pcDNA3-GATA4 or pcDNA3GATA5, selected for $10 \mathrm{~d}$ with G418 $(400 \mu \mathrm{g} / \mathrm{mL})$, and these heterogeneous cell populations, named pc-con, pc-GATA4, and pcGATA5, respectively, were used for further experiments using medium without G418. For real-time reverse transcription-PCR, Western Blot, colony formation, cell proliferation, migration, invasion, and anchorageindependent growth assays, see Supplementary Methods.

Collection of fecal DNA. Colonoscopy negative control stool samples $(n=75)$ were obtained from a population of healthy subjects over $50 \mathrm{y}$ of age who were screened within the framework of a workplace-based community colorectal cancer screening study at the Maastricht University Medical Center. The Medical Ethics Committee of the Maastricht University Medical Center and the Dutch Health Council approved the study. Stool samples from colonoscopy-confirmed colorectal cancer patients $(n=75)$ were collected at the VU University Medical Center in Amsterdam. For the subjects' characteristics, see Supplementary Table S3. Written informed consent was obtained for all stool samples. Control stool samples and a subset of colorectal cancer samples were collected within $2 \mathrm{wk}$ prior to colonoscopy. Some colorectal cancer stool samples were collected 5 to $7 \mathrm{~d}$ following colonoscopy. Colorectal cancer stool samples were only collected when the tumor was not resected after colonoscopy. Stool samples were stored and processed (see Supplementary Methods section) in one center, and handled and analyzed in a blinded fashion during collection, storage, DNA isolation, and PCR analysis.

Quantitative MSP. Quantitative MSP (qMSP) was applied on a 7900HT fast real-time PCR system (Applied Biosystems). The PCR reaction was carried out in $12 \mu \mathrm{L}$ volume containing buffer [16.6 $\mathrm{mmol} / \mathrm{L}\left(\mathrm{NH}_{4}\right) 2 \mathrm{SO}_{4}, 67 \mathrm{mmol} / \mathrm{L}$ Tris, $6.7 \mathrm{mmol} / \mathrm{L} \mathrm{MgCl}_{2}, 10 \mathrm{mmol} / \mathrm{L}$ $\beta$-mercaptoethanol], $5 \mathrm{mmol} / \mathrm{L} \mathrm{dNTP}, 6 \mathrm{ng} / \mu \mathrm{L}$ forward primer, $18 \mathrm{ng} /$ $\mu \mathrm{L}$ reverse primer, $0.16 \mu \mathrm{mol} / \mathrm{L}$ molecular beacon, $0.1 \mu \mathrm{g}$ bovine serum albumin, 0.4 units Jumpstart DNA Taq polymerase (Sigma Aldrich), and $2.4 \mu \mathrm{L}$ DNA. Cycling parameters were $5 \mathrm{~min} 95^{\circ} \mathrm{C}$, followed by 45 cycles of $30 \sec 95^{\circ} \mathrm{C}, 30 \sec 57^{\circ} \mathrm{C}$ and $30 \sec 72^{\circ} \mathrm{C}$, followed by $5 \mathrm{~min}$ $72^{\circ} \mathrm{C}$. A standard curve $\left(2 \times 10^{6}-20\right.$ copies $)$ was included to determine copy numbers of unknown samples by interpolation of their $\mathrm{Ct}$ values to the standard curve. For primer and molecular beacon sequences, see Supplementary Table S2. Receiver operator characteristic (ROC) curve analysis was used to assess the best cutoff value (an optimal cutoff value was determined by the point on the ROC curve closest to $100 \%$ specificity and corresponding to the highest sensitivity), and to determine diagnostic performance, using the area under the curve. Positivity for GATA4 methylation was considered if a methylation value was higher than the cutoff. 
Statistical analysis. We used Pearson's $\chi^{2}$ or Fisher's exact test and the one-way ANOVA, Kruskal-Wallis, or Mann-Whitney test where appropriate to compare categorical and continuous patient data, respectively. Paired samples within the group of cases were analyzed using the Mc Nemar test and the paired $t$-test to compare categorical and continuous data, respectively. Because significant differences in age and location of the tissue were observed between colorectal cancer patients and controls (Supplementary Table S1), logistic regression analyses were used to adjust for age and location. Where appropriate, the Bonferroni method was used to correct for multiple comparisons. To examine sensitivity and specificity of every possible marker combination, WEKA System's Bayes Network machine learning was applied (27). In vitro cell line experiments are given as mean values \pm SE. Analysis of cell growth curves was done by means of the two-way ANOVA test. Student's $t$-test was used for analyses of ${ }^{3} \mathrm{H}$-thymidine incorporation and anchorage-independent growth. Colony formation assay, quantitative real-time reverse transcription-PCR, migration, and invasion assays analyses were done using the Mann-Whitney rank sum test. All $P$ values are two-sided and $P \leq 0.05$ was considered statistically significant. Statistical analysis was done in SPSS12.0.1.

\section{Results}

High frequencies of GATA4 and GATA5 methylation in colorectal carcinomas and adenomas. GATA4 methylation was detected in $70 \%(63 / 90)$ of colorectal carcinomas, whereas methylation of this gene was observed in only 5 of $88(6 \%)$ of normal colorectal tissues from noncancerous controls were methylated (Table $1, P<2 \times 10^{-11}$ ). Methylation frequencies of GATA5 were $79 \%(61 / 77)$ in colorectal carcinoma tissues and $13 \%(13 / 100)$ in noncancerous controls (Table $1, P<3 \times 10^{-14}$ ). GATA4/5 were $86 \%$ concomitantly methylated and $83 \%$ concomitantly unmethylated in colorectal carcinomas $(P<$ $0.01 \times 10^{-17}$; data not shown). Because promoter methylation has been described in inflammatory conditions of the gastrointestinal tract $(17-19)$, inflamed colorectal mucosa of noncancerous patients was added to the control group (Table 1). This did not significantly increase GATA4/5 methylation (7\% and $12 \%$, respectively; Table 1 ).

Comparing the frequencies of GATA4/5 methylation with those of other genes reported to be frequently methylated in colorectal cancer (APC, $p 14^{A R F}, O^{6}-M G M T, H L T F, p 16^{I N K 4 A}$, and and RASSF1A; refs. 28-30; Table 1) showed that GATA4/5 do best in terms of specificity and sensitivity, respectively (Table 1). Furthermore, Bayesian network analysis showed that the sensitivity of GATA4/5 methylation alone did not improve by adding any of the other markers. In addition, no other combination of methylation markers has a higher sensitivity as compared with GATA4/5 alone (data not shown). No correlation was observed between GATA4/5 methylation and the V600E BRAF mutation (found in $13 \%$ of all carcinomas; $13 / 98$ ) or microsatellite instability status (found in $15 \%$ of all carcinomas; 15/101; data not shown).

A second independent series of colorectal cancers (NLCS; refs. 24, 25) confirms the high frequency of GATA4 (65\%; 369/ $572)$ and GATA5 (74\%; 440/592) methylation (data not shown). Furthermore, GATA4/5 promoter methylation was not significantly associated with tumor-node-metastasis (TNM) stage, tumor location, sex, age at diagnosis, histologic type, or grade of differentiation in both series (Table 2 and data not shown).

GATA4/5 methylation frequencies of adenomas that developed synchronously or metachronously to the tumor $(n=75)$ and adenomas obtained from noncancerous patients $(n=72$; 10-year follow-up) did not show significant differences between these two groups (Supplementary Table S4). No association of GATA4/5 methylation with grade of dysplasia was observed, but more GATA4 methylation in tubulovillous as compared with tubular adenomas was observed $(P<0.0001$, data not shown). Frequencies of GATA4/5 methylation were not significantly different between normal colon mucosa obtained from colorectal cancer patients and noncancerous controls (Supplementary Table S4). No association was found between GATA4/5 promoter methylation in normal noncancerous tissue and age at biopsy, sex, or location of the normal tissue (data not shown).

Adenoma samples from colorectal cancer patients exhibited significantly higher GATA4/5 methylation frequencies than normal colon mucosa from these patients $(P<0.002$ and $P<0.0005$, respectively; Supplementary Table S5). Significantly higher GATA4/5 methylation frequencies were observed in colorectal cancers when compared with normal colon from colorectal cancer patients $\left(P<4 \times 10^{-7}\right.$ and $P<2 \times 10^{-7}$,

\begin{tabular}{|c|c|c|c|c|c|}
\hline & \multirow{2}{*}{$\frac{\text { CRC+ }}{\text { Carcinoma }}$} & \multirow{2}{*}{$\begin{array}{c}\text { CRC- } \\
\text { Normal }\end{array}$} & \multirow[t]{2}{*}{$\boldsymbol{P}^{*}(<)$} & \multirow{2}{*}{$\frac{\text { CRC- }}{\text { Normal plus inflamed }}$} & \multirow[t]{2}{*}{$P^{*}(<)$} \\
\hline & & & & & \\
\hline GATA4 & $63 / 90(70 \%)$ & $5 / 88(6 \%)$ & $2 \times 10^{-11}$ & $8 / 119(7 \%)$ & $4 \times 10^{-14}$ \\
\hline GATA5 & $61 / 77(79 \%)$ & $13 / 100(13 \%)$ & $3 \times 10^{-14}$ & $16 / 129(12 \%)$ & $3 \times 10^{-16}$ \\
\hline$A P C$ & $47 / 100(47 \%)$ & $24 / 103(23 \%)$ & $2 \times 10^{-3}$ & $32 / 132(24 \%)$ & $9 \times 10^{-4}$ \\
\hline$p 14 A R F$ & $37 / 86(43 \%)$ & $15 / 105(14 \%)$ & $2 \times 10^{-4}$ & $19 / 134(14 \%)$ & $4 \times 10^{-5}$ \\
\hline O6-MGMT & $50 / 96(52 \%)$ & $21 / 105(20 \%)$ & $2 \times 10^{-5}$ & $30 / 139(22 \%)$ & $9 \times 10^{-6}$ \\
\hline HLTF & $50 / 96(52 \%)$ & $19 / 103(18 \%)$ & $7 \times 10^{-5}$ & $21 / 134(16 \%)$ & $2 \times 10^{-6}$ \\
\hline p16INK4A & $59 / 95(62 \%)$ & $14 / 68(21 \%)$ & $3 \times 10^{-7}$ & $25 / 97(26 \%)$ & $5 \times 10^{-7}$ \\
\hline RASSF1A & $25 / 100(25 \%)$ & $14 / 101(14 \%)$ & ns & $16 / 131(12 \%)$ & $2 \times 10^{-2}$ \\
\hline
\end{tabular}

NOTE: Methylation frequencies are represented as the number of methylated samples/(divided by) the total number of samples analyzed (percentage). Logistic regression was used to adjust for age and location.

Abbreviations: CRC+, colorectal cancer patients; CRC-, noncancerous individuals; ns, not significant.

* Bonferroni-corrected $P$ value. 
Table 2. GATA4/5 methylation frequencies in relation to clinicopathologic features of colorectal carcinoma tissue

\begin{tabular}{lrr} 
& \multicolumn{1}{c}{ GATA4 } & \multicolumn{1}{c}{ GATA5 } \\
\hline TNM stage & & \\
I & $11 / 15(73 \%)$ & $13 / 15(87 \%)$ \\
II & $21 / 32(66 \%)$ & $21 / 29(74 \%)$ \\
III & $25 / 34(74 \%)$ & $19 / 25(76 \%)$ \\
IV & $6 / 9(67 \%)$ & $8 / 8(100 \%)$ \\
Tumor Location & & \\
$\quad$ Proximal & $32 / 41(78 \%)$ & $31 / 36(86 \%)$ \\
$\quad$ Distal & $31 / 47(66 \%)$ & $29 / 39(74 \%)$ \\
Sex & & \\
$\quad$ Male & $29 / 42(69 \%)$ & $29 / 37(78 \%)$ \\
$\quad$ Female & $34 / 48(71 \%)$ & $32 / 40(80 \%)$ \\
Age at diagnosis* & & \\
$\quad$ mean & $28 / 38(74 \%)$ & $26 / 34(76 \%)$ \\
> mean & $35 / 52(67 \%)$ & $35 / 43(81 \%)$ \\
Histologic type & & \\
$\quad$ Adenocarcinoma & $50 / 75(67 \%)$ & $49 / 65(75 \%)$ \\
$\quad$ Mucinous carcinoma & $13 / 15(87 \%)$ & $12 / 12(100 \%)$ \\
Differentiation & $6 / 8(75 \%)$ & $6 / 7(86 \%)$ \\
$\quad$ Poor & $52 / 71(73 \%)$ & $47 / 59(80 \%)$ \\
$\quad$ Moderate & $5 / 11(46 \%)$ & $8 / 11(73 \%)$ \\
$\quad$ Well & & \\
\hline
\end{tabular}

NOTE: No significant correlations were found.

*Individuals are divided into two groups: those with an age smaller than or equal to the mean age of the study population and those with an age higher than the mean age.

respectively). Although more methylation of GATA4/5 was observed in carcinomas than in adenomas from colorectal cancer patients, this was not statistically significant (Supplementary Table S5).
Reduced colony formation and proliferation of colorectal cancer cells by GATA4 and GATA5. The high frequency of GATA4/5 promoter methylation, as well as the frequent loss of the GATA4 locus (8p23.1-p22), suggests that silencing these genes might confer a selection advantage. Therefore, expression constructs harboring full-length GATA4/5 cDNA were introduced into RKO in which GATA4 is present but GATA5 is silenced (22), showing reduced numbers of G418-resistant colonies ( $86 \%$ and $76 \%$ reduction, respectively) compared with transfection of empty vector (Fig. 1A; $P<0.005$ ). Comparable results were found when using HCT116, in which both GATA4/ 5 are absent (ref. 22; Fig. 1B).

Single colonies of RKO and HCT116 transfectants were picked and expanded. For RKO, one clone with constitutively higher levels of GATA4 mRNA and protein than control transfectants was obtained (pc-GATA4-1), and one clone stably expressing GATA5 (pc-GATA5-1; Fig. 2A). Cell growth of three RKO control clones constitutively expressing empty vector (pccon-1, -2, -3) was comparable and averaged [pc-con(1-3)], and proliferation of the GATA4/5 clones was significantly reduced compared with control clones (Fig. $2 \mathrm{~B}$ and $\mathrm{C}$ ). In contrast to RKO, HCT116 single-cell clones stably expressing GATA4/5 protein could not be maintained. Therefore, these cells were transiently transfected and selected with G418 for 10 days, and then seeded for functional assays. GATA4 and GATA5 transfectants expressed mRNA and protein of GATA4 and GATA5, respectively, and showed significantly decreased proliferation (32\% and $45 \%$ inhibition after 5 days, respectively) as compared with control transfectants (pc-con; Supplementary Fig. S2). The percentage of cells with sub-diploid DNA content was measured using flow cytometry, but no differences in apoptosis or total cell death were observed (data not shown).

GATA4 and GATA5 suppress migration, invasion, and anchorageindependent growth of colorectal cancer cells. We next examined
Fig. 1. GATA4 and GATA5 inhibit colony formation of human colorectal cancer cells. $A$ and $B$, colony formation of RKO $(A)$ and HCT116 $(B)$ cells transfected with a control vector (pc-con) or a GATA4 (pc-GATA4) or GATA5 (pc-GATA5) expression vector and selected for 2 wk with G418.

Quantification of colony formation is presented as mean values $( \pm S E)$ relative to control transfectants (pc-con) of three independent experiments $\left({ }^{*} P<0.005\right)$.

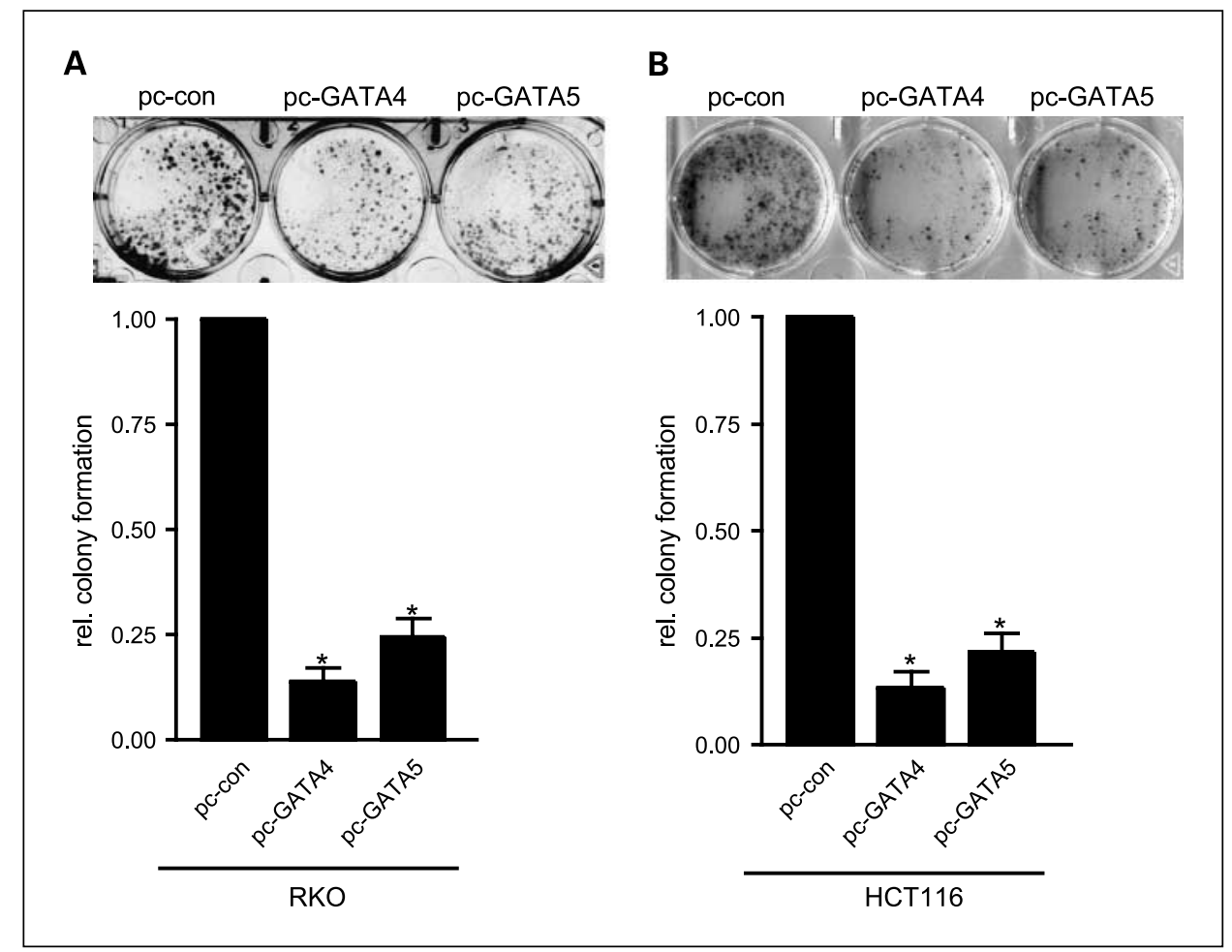


A

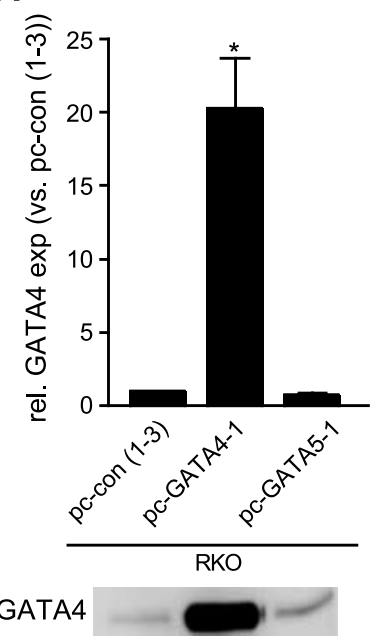

B

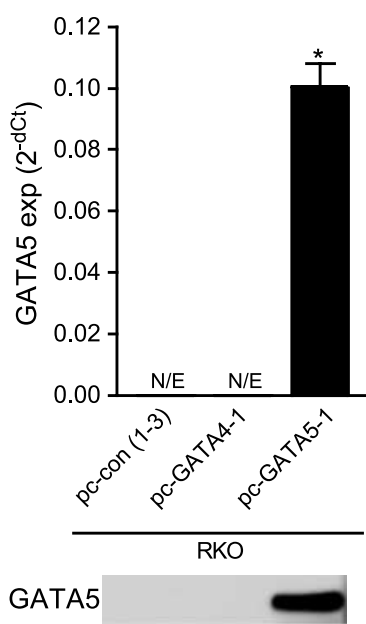

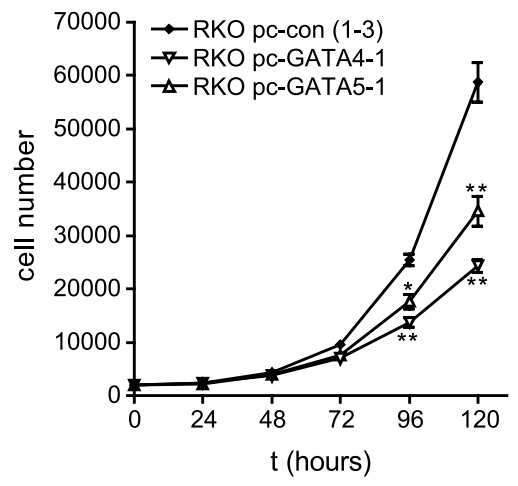

C

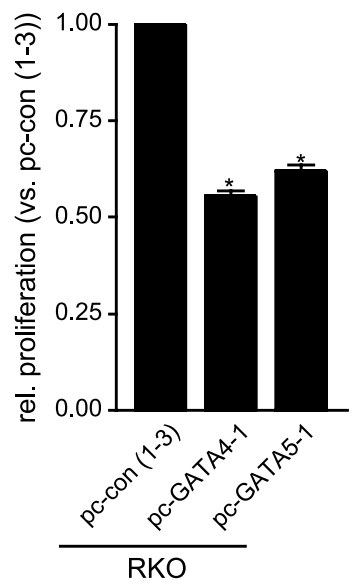

Fig. 2. GATA4 and GATA5 inhibit proliferation of human colorectal cancer cells. $A$, bar graphs, GATA4 and -5 mRNA expression measured by real-time reverse transcription-PCR in RKO monoclonal cell lines. The pc-GATA4-1 and pc-GATA5-1 clones constitutively express GATA4 and -5, respectively, and pc-con(1-3) represents the average of three control (empty pcDNA3 vector) clones. Results are plotted as mean values ( \pm SE) of relative mRNA expression compared with pc-con (1-3) (GATA4) or as mean values ( $\pm \mathrm{SE}$ ) of expression (calculated as $2^{\text {-dCt} ; ~ G A T A 5) ~ o f ~ t h r e e ~ i n d e p e n d e n t ~ e x p e r i m e n t s ~[~} P<0.05$ versus pc-con $\left.(1-3)\right]$. N/E, not expressed. Gel images, Western blot analysis of GATA4 and GATA5 protein in nuclear extracts of RKO cells. Only 1 of 3 control clones are shown. $B$, cell growth of RKO monoclonal cell lines.

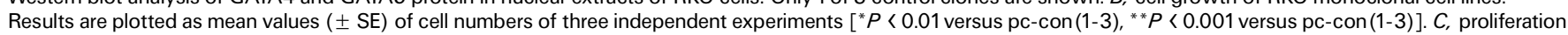
measured by $3 \mathrm{H}$-thymidine incorporation. Data are expressed as mean relative proliferation values $( \pm \mathrm{SE})$ compared with pc-con (1-3) of three independent triplicate experiments $\left[{ }^{*} P<0.0001\right.$ versus pc-con $\left.(1-3)\right]$.

the effects of GATA4/5 on migration and invasion of colorectal cancer cells using the modified Boyden chamber assay. Migration of GATA4/5 RKO clones was significantly lower when compared with control clones (Fig. 3A; $P<0.05$ ). This was confirmed in HCT116, showing significantly decreased migration of the GATA4/5-transfected cells (68\% and $73 \%$ inhibition, respectively) when compared with control transfectants (Fig. 3B). Invasion of GATA4 and GATA5 RKO clones through matrigel-layered transwell membranes was also lower than that of control clones (Fig. 3C; $P<0.05$ ). Similarly, the invasive activity of GATA4/5 HCT116 transfectants was also significantly reduced $(87 \%$ and $74 \%$ inhibition, respectively) compared with empty vector transfected cells (Fig. 3D and Supplementary Fig. S3). Anchorageindependent growth of RKO monoclonal cell lines was assessed by soft agar colony formation. The number of colonies formed by GATA4/5 RKO clones was significantly lower (59\% and 66\% inhibition, respectively) compared with control clones (Supplementary Fig. S4; $P<0.0001)$. Furthermore, GATA4/5 colonies were smaller than those produced by control transfectants (Supplementary Fig. S4).

GATA4 methylation in fecal DNA as a potential biomarker for colorectal cancer detection. Because GATA4 methylation was most specific (Table 1) and addition of GATA5 did not significantly increase sensitivity compared with GATA4 alone (data not shown), we further analyzed GATA4 methylation in fecal DNA as a potential biomarker. Stool samples were collected from colorectal cancer patients $(n=28)$, covering all stages of colorectal cancer, and 45 colonoscopy negative controls. GATA4 methylation of fecal DNA was determined by qMSP. The area under the curve in the ROC curve was $81 \%$
[95\% confidence interval (95\% CI), 70-89\%]; Fig. 4. The optimal GATA4 methylation cutoff value was 8.1 (Fig. 4). Using this cutoff, GATA4 methylation was detected in fecal DNA from 20 of 28 patients and in 7 of the 45 control individuals, yielding a sensitivity of $71 \%(95 \% \mathrm{CI}, 55-88 \%)$ and a specificity of $84 \%$ (95\% CI, 74-95\%). Because the mean age of the cases and controls differed significantly, ROC-GLM regression analysis was used to assess the accuracy of GATA4 promoter methylation after adjustment for age (31). Age did not significantly influence the accuracy $(P=0.71$, ROC-Generalized Linear Model regression model).

Sensitivity and specificity (using a GATA4 cutoff value 8.1) was validated in an independent set of stool samples from colorectal cancer patients $(n=47)$ and controls $(n=30)$. This resulted in a sensitivity of 51\% (95\% CI, 37-65\%) and a specificity of $93 \%$ (95\% CI, 84-100\%) of GATA4 methylation in fecal DNA.

Sensitivity of GATA4 promoter methylation in fecal DNA for detecting early-stage (TNM stage I and II) and advancedstage (TNM stage III and IV) colorectal cancer was 10 of 18 (55\%; early stage) versus 10 of 10 (100\%; advanced stage) for the training set, and 14 of 29 (48\%; early stage) versus 10 of 17 (59\%; advanced stage) in the validation set. Although this pilot study shows proof of principle for detecting GATA4 promoter methylation in stool, it seems that early-stage colorectal cancers shed less DNA when compared with advanced-stage colorectal cancers, which emphasizes the need for sensitive assays to isolate/capture DNA from early-stage colorectal cancers.

For a subset $(n=19)$ of cases of which fecal DNA was examined for GATA4 promoter CpG island methylation, the 
matching formalin-fixed paraffin-embedded primary tumor tissue was available. GATA4 promoter methylation was detected in 16 of 19 primary colorectal cancers, and 10 of these 16 colorectal cancers also exhibited methylation in the matched stool samples, yielding an analytical sensitivity of $63 \%$ (95\% CI, 39-86\%; data not shown).

\section{Discussion}

Loss of GATA4/5 expression due to promoter hypermethylation has been reported in primary colorectal, gastric, esophageal, lung, ovarian, and pancreatic (GATA5 only) cancer $(22,32-35)$. To analyze the potential of GATA4/5 as methylation markers for detection of colorectal cancer, we analyzed large series of colorectal cancer patients and controls and showed that methylation of GATA4 (70\%) and GATA5 $(79 \%)$ occurs at high frequencies in colorectal cancers and at low levels in normal colorectal mucosa (6 and 13\%, respectively). Methylation frequencies of GATA4/5 are not increased in inflammatory colorectal tissues. GATA4/5 methylation is highly prevalent in colorectal adenomas, suggesting that methylation of GATA4/5 is an early event in colorectal carcinogenesis. Lack of association of GATA4/5 methylation with clinicopathologic characteristics indicates that GATA4/5 methylation may be equivalently sensitive to early- and latestage colorectal cancer, and to proximal as well as distal colorectal cancer, thereby covering all colorectal cancer phenotypes, including microsatellite instable and chromosomal instable tumors. These findings indicate that methylation of GATA4/5 may be suitable markers for early diagnosis of colorectal cancer.

Methylation analysis of six other genes frequently and functionally methylated in colorectal cancer $(28-30)$ showed frequent methylation of APC, $p 16^{I N K 4 A}$, and $O^{6}-M G M T$ in normal and inflamed colorectal mucosa. Whether methylation of $A P C$ and $p 16^{I N K 4 A}$ in normal colorectal mucosa represents a field effect (and thus a prognostic marker) as was published for $\mathrm{O}^{6}$-MGMT (36) is not clear from this study.

Well-defined molecular markers will be helpful for noninvasive early diagnosis of colorectal cancer and might reduce mortality from this disease. The combined sensitivity and specificity of GATA4 methylation for colorectal cancer detection compares well with other fecal DNA methylation markers such as SFRP2, vimentin, and HIC1 (10, 11, 15). Nevertheless, increasing the sensitivity of GATA4 methylation in fecal DNA is required to increase the applicability of this screening test. A higher sensitivity for the stool GATA4 MSP test could be
Fig. 3. GATA4 and GATA5 decrease migration and invasion of human colorectal cancer cells. $A$ and $B$, migration of RKO cell clones $(A)$ and HCT116 cells $(B)$ through transwells without matrigel, measured by direct counting of trespassed cells. Data are presented as mean relative numbers $( \pm$ SE) of migrated cells from several fields $(200 \times)$ of two independent experiments $\left[{ }^{*} P<0.05\right.$ versus pc-con(1-3) $(A)$ or versus pc-con $(B)]$. $C$ and $D$, invasion of RKO cell clones $(C)$ and HCT116 cells $(D)$ through transwells with matrigel. Results represent mean relative counts $( \pm$ SE) of trespassed cells from several fields $(200 \times)$ of two independent experiments $\left[{ }^{*} P<0.05\right.$ versus pc-con $(1-3)(C)$ or versus pc-con $(D)]$
A

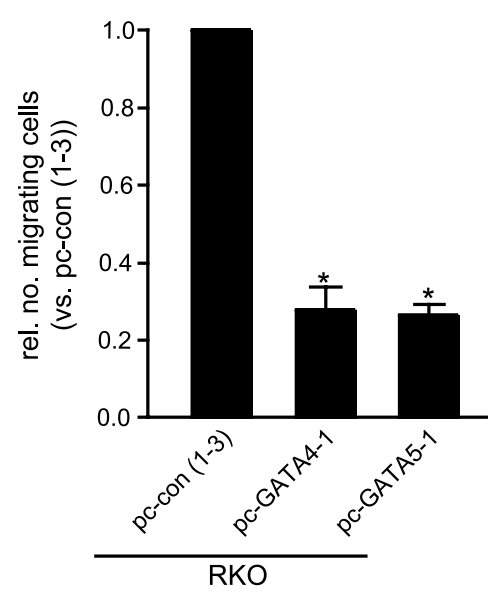

C

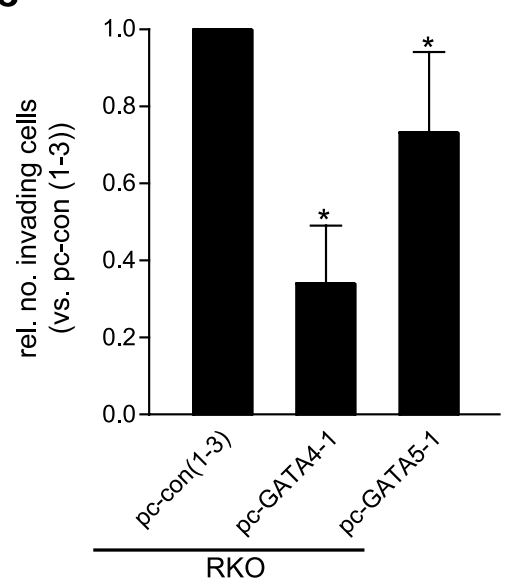

B

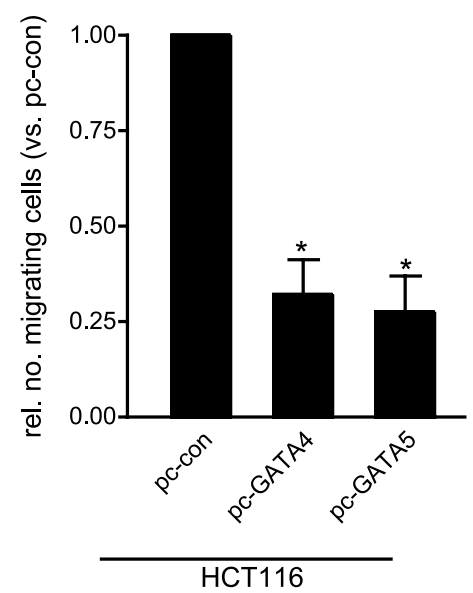

D

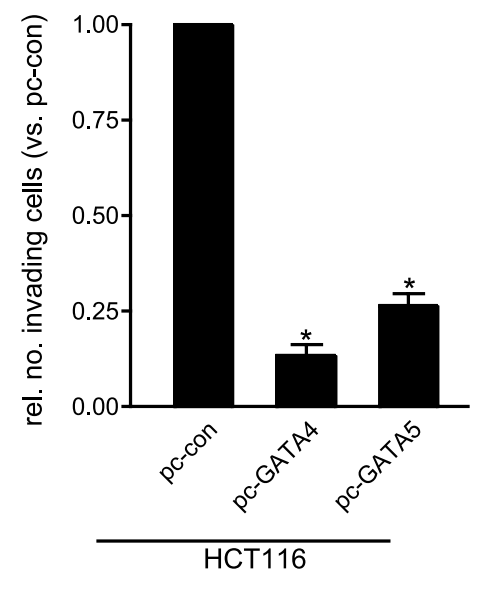




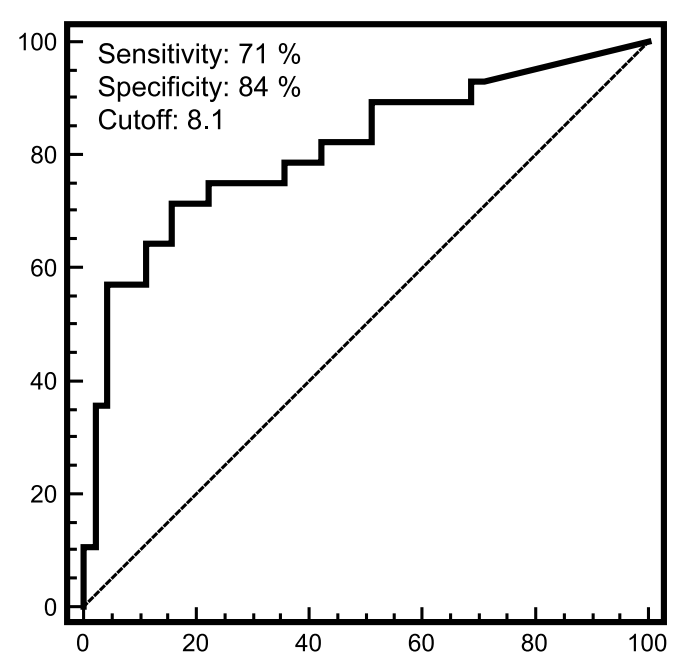

Fig. 4. GATA4 methylation in fecal DNA as a biomarker for colorectal cancer detection. ROC curve for GATA4 methylation considering 28 colorectal cancer stool samples and 45 normal control stool samples. The ROC curve displays the estimated sensitivity and specificity at various cutoff values for defining a positive test for GATA4 qMSP. The determined optimal cutoff value for GATA4 methylation was 8.1.

achieved using optimal isolation protocols for fecal DNA. For example, using methyl binding domain protein columns to capture methylated DNA, which have been shown to markedly increase sensitivity without decreasing specificity (37), could be interesting in this respect. Also, identification of complementary (epi)genetic markers is required in order to obtain a multigene assay to augment the diagnostic accuracy of fecal DNA testing. Machine learning has revealed that neither addition of any of the other genes we tested nor a different gene panel outdoes the sensitivity of GATA4 and GATA5 methylation in primary colorectal carcinomas. This indicates that none of the other genes were complementary to the GATA4/5 markers in primary colorectal carcinomas, and suggests the existence of a subset of colorectal cancers with extensive promoter methylation and a subset without methylation of the markers tested in this study. When comparing GATA4 methylation in stool DNA with the corresponding tumor tissue, two cases were identified in which GATA4 methylation was found in stool DNA in the absence of methylation in the associated colorectal cancer tissue. This discrepancy might be due to the stool sample containing tumor cells from an area separate from where the tissue DNA was extracted, reflecting heterogeneity of GATA4 promoter methylation in the tumor, or might be derived from additional tumors located upstream in the gastrointestinal tract such as esophageal or gastric tumors. In addition, the analytical sensitivity of $63 \%$ reveals that some of the patients with GATA4 methylation in the primary colorectal cancer lacked methylation in the stool, which might result from the situation that detectable amounts of tumor cells may not have shed into the feces when it was collected.

For methylation analysis of stool DNA, qMSP was the method of choice, because this approach allows robust and sensitive automated analysis of clinical samples for use in molecular screening approaches, and the specificity of this approach is enhanced by using labeled internal probes.

GATA4/5 have been implicated in cancer development, in which they would behave as tumor suppressors by activating the promoters of antitumor genes $(22,38)$. However, to our knowledge, the tumor suppressive effects of these genes have never been reported in colorectal cancer, but only in GATA4transfected ovarian tumor cells (38). Here, we show that introduction of GATA4/5 into human colorectal cancer cell lines by transient and stable transfection results in inhibition of colony formation, cell growth, migration, invasion, and anchorage-independent growth in vitro, suggesting that these genes are relevant tumor suppressor genes in colorectal cancer. However, the downstream target genes of GATA4/5 inducing the above mentioned effects remain to be identified.

In conclusion, we found that GATA4/5 exhibit tumor suppressive activities in colorectal cancer cells in vitro and show that promoter hypermethylation of GATA4/5 is frequent and specific in primary colorectal cancers. GATA4 methylation in fecal DNA has potential to be used in a biomarker panel for improving preselection tests for colonoscopy.

\section{Disclosure of Potential Conflicts of Interest}

J. Louwagie, W. van Criekinge, employment, OncoMethylome Sciences. M. van Engeland, G.A. Meijer, J.G. Herman, S.B. Baylin, commercial research grant, OncoMethylome Sciences. J.G. Herman, S.B. Baylin, G.A. Meijer, consultant, OncoMethylome Sciences. The commercial rights to the MSP technique belong to OncoMethylome Sciences. J.G. Herman and S.B. Baylin are entitled to royalties from any commercial use of the MSP technique.

\section{Acknowledgments}

We are grateful to Edith van der Linden for technical support with preparation of single colonies of colorectal cancer cells.

\section{References}

1. Mandel JS, Bond JH, Church TR, et al. Reducing mortality from colorectal cancer by screening for fecal occult blood. Minnesota Colon Cancer Control Study. N Engl J Med 1993:328:1365-71.

2. Kronborg O, Fenger C, Olsen J, Jorgensen OD, Sondergaard $\mathrm{O}$. Randomised study of screening for colorectal cancer with faecal-occult-blood test. Lancet 1996;348:1467-71.

3. Winawer SJ, Zauber AG, Ho MN, et al. Prevention of colorectal cancer by colonoscopic polypectomy. The National Polyp Study Workgroup. N Engl J Med 1993; 329:1977-81.

4. Hardcastle JD, Chamberlain JO, Robinson $\mathrm{MH}$, et al Randomised controlled trial of faecal-occult-blood screening for colorectal cancer. Lancet 1996;348: $1472-7$.

5. Kewenter J, Brevinge $H$, Engaras B, Haglind E, Ahren C. Follow-up after screening for colorectal neoplasms with fecal occult blood testing in a controlled trial. Dis Colon Rectum 1994:37:115 - 9.

6. Traverso G, Shuber A, Levin B, et al. Detection of APC mutations in fecal DNA from patients with colorectal tumors. N Engl J Med 2002;346:311 - 20.

7. Dong SM, Traverso G, Johnson C, et al. Detecting colorectal cancer in stool with the use of multiple genetic targets. J Natl Cancer Inst 2001;93:858-65.

8. Imperiale TF, Ransohoff DF, Itzkowitz $\mathrm{SH}$, Turnbull BA, Ross ME. Fecal DNA versus fecal occult blood for colorectal-cancer screening in an average-risk population. N Engl J Med 2004;351:2704-14.

9. Diehl F, Schmidt K, Durkee KH, et al. Analysis of mutations in DNA isolated from plasma and stool of colorectal cancer patients. Gastroenterology 2008; 135:489-98.

10. Chen WD, Han ZJ, Skoletsky J, et al. Detection in fecal DNA of colon cancer-specific methylation of the nonexpressed vimentin gene. J Natl Cancer Inst 2005;97:1124-32.

11. Muller HM, Oberwalder M, Fiegl $\mathrm{H}$, et al. Methylation changes in faecal DNA: a marker for colorectal cancer screening? Lancet 2004;363:1283-5.

12. Sanchez-Cespedes M, Esteller M, Wu L, et al. Gene 
promoter hypermethylation in tumors and serum of head and neck cancer patients. Cancer Res 2000;60: $892-5$.

13. Belinsky SA, Liechty KC, Gentry FD, et al. Promoter hypermethylation of multiple genes in sputum precedes lung cancer incidence in a high-risk cohort. Cancer Res 2006;66:3338-44.

14. Hoque MO, Begum S, Topaloglu O, et al. Quantitation of promoter methylation of multiple genes in urine DNA and bladder cancer detection. J Natl Cancer Inst 2006;98:996-1004

15. Lenhard K, Bommer GT, Asutay S, et al. Analysis of promoter methylation in stool: a novel method for the detection of colorectal cancer. Clin Gastroenterol Hepatol 2005;3:142-9.

16. Issa JP, Ottaviano $Y L$, Celano $P$, Hamilton SR, Davidson NE, Baylin SB. Methylation of the oestrogen receptor $\mathrm{CpG}$ island links ageing and neoplasia in human colon. Nat Genet 1994;7:536-40.

17. Sato F, Harpaz N, Shibata D, et al. Hypermethylation of the p14(ARF) gene in ulcerative colitis-associated colorectal carcinogenesis. Cancer Res 2002;62:1148-51.

18. Issa JP, Ahuja N, Toyota M, Bronner MP, Brentnall TA. Accelerated age-related $\mathrm{CpG}$ island methylation in ulcerative colitis. Cancer Res 2001;61:3573-7.

19. Hsieh CJ, Klump B, Holzmann K, Borchard F, Gregor M, Porschen R. Hypermethylation of the p16INK4a promoter in colectomy specimens of patients with long-standing and extensive ulcerative colitis. Cancer Res 1998;58:3942-5.

20. Molkentin JD. The zinc finger-containing transcription factors GATA-4, -5 , and -6. Ubiquitously expressed regulators of tissue-specific gene expression. J Biol Chem 2000;275:38949-52.
21. Gao X, Sedgwick T, Shi YB, Evans T. Distinct functions are implicated for the GATA- $4,-5$, and -6 transcription factors in the regulation of intestine epithelial cell differentiation. Mol Cell Biol 1998;18:2901 -11.

22. Akiyama $Y$, Watkins $N$, Suzuki $H$, et al. GATA- 4 and GATA- 5 transcription factor genes and potential downstream antitumor target genes are epigenetically silenced in colorectal and gastric cancer. Mol Cell Biol 2003;23:8429-39.

23. Fujiwara $Y$, Emi $M$, Ohata $H$, et al. Evidence for the presence of two tumor suppressor genes on chromosome 8p for colorectal carcinoma. Cancer Res 1993; 53:1172-4.

24. Brink M, de Goeij AF, Weijenberg MP, et al. K-ras oncogene mutations in sporadic colorectal cancer in The Netherlands Cohort Study. Carcinogenesis 2003;24:703-10.

25. van Engeland $M$, Weijenberg MP, Roemen GM, et al. Effects of dietary folate and alcohol intake on promoter methylation in sporadic colorectal cancer: the Netherlands cohort study on diet and cancer. Cancer Res 2003;63:3133-7.

26. Herman JG, Graff JR, Myohanen S, Nelkin BD, Baylin SB. Methylation-specific PCR: a novel PCR assay for methylation status of $\mathrm{CpG}$ islands. Proc Natl Acad Sci U S A 1996;93:9821 -6.

27. Witten IH, Frank E, Kaufmann M. Data mining: practical machine learning tools with Java implementations. San Francisco (CA): Morgan Kaufmann Publishers; 2000.

28. Esteller M, Corn PG, Baylin SB, Herman JG. A gene hypermethylation profile of human cancer. Cancer Res 2001;61:3225-9.

29. van Engeland $M$, Roemen GM, Brink $M$, et al. K-ras mutations and RASSF1A promoter methylation in colorectal cancer. Oncogene 2002;21:3792-5.

30. Moinova HR, Chen WD, Shen L, et al. HLTF gene silencing in human colon cancer. Proc Natl Acad Sci U S A 2002;99:4562-7.

31. Janes $\mathrm{H}$, Longton GM, Pepe M. Accommodating covariates in ROC analysis. UW Biostatistics Working Paper Series 2008;Working paper 322.

32. Guo M, AkiyamaY, House MG, et al. Hypermethylation of the GATA genes in lung cancer. Clin Cancer Res 2004;10:7917-24.

33. Guo M, House MG, AkiyamaY, et al. Hypermethylation of the GATA gene family in esophageal cancer. In J Cancer 2006;119:2078-83.

34. Wakana K, Akiyama Y, Aso T, Yuasa Y. Involvement of GATA-4/-5 transcription factors in ovarian carcinogenesis. Cancer Lett 2006;241:281 -8.

35. Fu B, Guo M, Wang $S$, et al. Evaluation of GATA-4 and GATA- 5 methylation profiles in human pancreatic cancers indicate promoter methylation patterns distinct from other human tumor types. Cancer Biol Ther 2007;6:1546-52.

36. Shen L, KondoY, Rosner GL, et al. MGMT promoter methylation and field defect in sporadic colorectal cancer. J Natl Cancer Inst 2005;97:1330-8.

37. Zou H, Harrington J, Rego RL, Ahlquist DA. A novel method to capture methylated human DNA from stool: implications for colorectal cancer screening Clin Chem 2007;53:1646-51.

38. Capo-chichi CD, Roland IH, Vanderveer L, et al. Anomalous expression of epithelial differentiationdetermining GATA factors in ovarian tumorigenesis. Cancer Res 2003;63:4967-77. 


\section{Clinical Cancer Research}

\section{GATA4 and GATA5 are Potential Tumor Suppressors and Biomarkers in Colorectal Cancer}

Debby M.E.I. Hellebrekers, Marjolein H.F.M. Lentjes, Sandra M. van den Bosch, et al.

Clin Cancer Res 2009;15:3990-3997.

Updated version Access the most recent version of this article at:

http://clincancerres.aacrjournals.org/content/15/12/3990

Supplementary Access the most recent supplemental material at:

Material http://clincancerres.aacrjournals.org/content/suppl/2009/06/15/1078-0432.CCR-09-0055.DC1

Cited articles This article cites 36 articles, 16 of which you can access for free at:

http://clincancerres.aacrjournals.org/content/15/12/3990.full\#ref-list-1

Citing articles This article has been cited by 21 HighWire-hosted articles. Access the articles at:

http://clincancerres.aacrjournals.org/content/15/12/3990.full\#related-urls

E-mail alerts Sign up to receive free email-alerts related to this article or journal.

Reprints and To order reprints of this article or to subscribe to the journal, contact the AACR Publications Subscriptions Department at pubs@aacr.org.

Permissions To request permission to re-use all or part of this article, use this link http://clincancerres. aacrjournals.org/content/15/12/3990.

Click on "Request Permissions" which will take you to the Copyright Clearance Center's (CCC)

Rightslink site. 